\title{
THE ROLE OF THE TAX ON IMMOVABLE PROPERTY IN THE MUNICIPAL BUDGETS IN THE CZECH REPUBLIC
}

\author{
[Úloha daně z nemovitostí v obecních rozpočtech v České republice]
}

\author{
Břetislav Andrlík ${ }^{1}$, Lucie Formanová ${ }^{2}$ \\ ${ }^{1}$ Mendel University in Brno, Faculty of Business and Economics, Zemědělská 1, 61300 Brno, Czech Republic \\ Email:bretislav.andrlik@mendelu.cz. \\ ${ }^{2}$ Mendel University in Brno, Faculty of Business and Economics, Zemédělská 1, 61300 Brno, Czech Republic \\ Email:xformano@pef.mendelu.cz
}

\begin{abstract}
The aim of this paper is to evaluate the effects of the fiscal decentralization in the conditions of the Czech Republic and to assess the significance of the tax on immovable property in the budgets of the municipal units. The tax on immovable property is the tax that plays from the point of the fiscal decentralization a significant role. In the Czech Republic the tax on immovable property is the income of the municipality under Act no. 243/2000 Coll., on the budgetary allocation of taxes from certain taxes to municipal authorities and to some state tax funds, so the municipality can, simultaneously due to $\S 12$ of Act no. 338 / 1992 Coll., on the tax on immovable property, as amended, directly affect the amount of the resulting tax liability of the taxpayers flowing to its public budget. The application of this legal instrument in the Czech Republic is discussed in a separate section of the analysis of the significance of the tax on immovable property. The article also includes the budget allocation of this tax in the Member States of the European Union. Theoretical research of this paper is aimed to identify factors that support the existence of this tax in modern tax systems. The analysis of the significance of the tax on immovable property is performed on the data from 2012, available from the portal "Municipal budget". The results achieved during own calculations indicate the importance of the tax on immovable property in the budgets of municipalities.
\end{abstract}

Keywords: local coefficient, municipality, tax on immovable property, tax system.

JEL classification: H20, H71

Doručeno redakci: 9.6.2015; Recenzováno: 17.6.2015; 17.6.2015; Schváleno k publikování: 23.9.2015

\section{Introduction}

From the theoretical point of view it is possible to interpret the causes of the existence of the analyzed tax in the tax systems of the modern market economies as follows. Musgrave and Musgrave (1994) proceed with the idea that the main reasons for taxation of assets are derived from the principle of utility, respectively the ability of the tax payment. Taxation according to the principle of utility (benefit) can be regarded as payment, which flows from the citizens to public budgets from which subsequently the public goods and services (e.g. infrastructure, police protection, etc.) are paid. It is important to realize that these goods and services can significantly increase the value of the immovable property of the taxpayers, which may be one reason why taxes classified according to the OECD methodology to a group of 4100 (recurrent tax on immovable property) are still applied in the most countries of the European Union. Andrlík and Formanová (2014) state that it is a part of the tax system in total 26 out of the 28 EU Member States, the Czech Republic is not an exception. The analyzed tax is there currently known as the tax on immovable property. With effect from January 1, 2014 there have been significant changes in private law, which mainly included the formation of a new Civil Code - Act no. 89/2012 Coll. These facts have forced the implementation of the significant changes in the tax field, property taxes were no exception. It is also the reason why the statutory regulation of the analyzed tax was revised by the Statutory provision of the Senate no. 344/2013 Coll., on the change of the tax laws in connection with the recodification 
of the private law, and therefore renamed from the real estate tax to the tax on immovable property (Act no. 338 / 1992 Coll., as amended). The explanatory report of MF of the Czech Republic states that the failure in the implementation of the above mentioned revision would significantly limit the subject of the tax or the formation of interpretative ambiguity, which is something that could have a negative impact on the development of tax collections. Based on the above mentioned changes in the name of the analyzed tax, we will use the abbreviation "TIP" for the simplicity and uniformity of the terminology in the following article. This abbreviation includes the name of the analyzed tax before and after the revision, which was necessitated by the recodification of the private law.

Kubátová (2010), Andrlík (2010), Jackson and Brown (2003) come with another argument supporting the existence of the analyzed tax and they agree that the imposition of tax on immovable property will contribute to a more rational management of the immovable property. The owners of the immovable property, who are liable to pay the tax on immovable property, are motivated to more effective treatment with the immovable property. It can be said that the analyzed tax can also have positive effects, which can be seen in the more responsible behaviour of the owners when dealing with immovable property. Kubátová (2010) concludes the list of positive qualities of the property taxes by stating that they can also have a function when reducing the inequities among taxpayers who properly pay income tax and those who commit tax evasion. Moreover, from a historical point of view, the immovable property create a considerable and relatively stable part of the property of population, which means that the collection of the tax on immovable property forms a relatively stable revenues for the public budgets.

Studied TIP, like other taxes in the tax system in the Czech Republic, is considered unpopular between taxpayers and therefore they would prefer its absolute elimination from the individual tax systems. They consider it as a tax, which causes a strong feeling of the multiple taxation of the obtained available funds of the taxpayers. Further, the specific feature of TIP is immovable nature of the tax subject, and due to the existence of accurate records within the land registers or inability to transfer the subject of the tax to another tax jurisdiction, there is practically no possibility to avoid paying taxes. As it was mentioned, the analyzed tax causes another (sometimes even multiple) taxation of the one already properly taxed sources of income performed e.g. by income tax. Therefore, it is often between taxpayers considered as a punishment for their success and often discussed in the context of the so-called double taxation. Kubátová (2010) notes that the critique applies to all property taxes, it also includes TIP. Opponents of the property taxes claim that it is not moral from the point of the principle of justice to punish those who have saved or their children that have been indirectly involved in the accumulated assets. Prabhakar (2008) emphasizes that the unpopularity or aversion is given mainly due to understanding property taxes as a double taxation of the same object. Generally people feel that they have already paid income tax during their active working lives and the property resulted from the accumulating of the taxed resources, thus the own existence of property tax is double taxation. However he explains this argument further and states that the double taxation occurs in any tax system, which consists of more taxes. A typical example of double taxation of income is the value added tax, as available income is taxed again when purchasing goods and services that are subject to this tax (food, cars, etc.). Some possibilities how to avoid the defined double taxation, is not to buy the goods, but the real possibility to avoid paying taxes on immovable property does not exist. Another factor that may deepen the aversion to the tax can be illustrated by looking at the tax environment of the Czech Republic, where every taxpayer is liable to establish and pay its tax liability in legitimate date. 
In contrast to these general arguments of the taxpayers there are also reasons to initiate discussion about their abolition on the other side, in case of beneficiary of the tax sources, public budgets. Because of these facts, the administrative costs of the tax authority are spent in order to obtain such tax sources. Pudil et al. (2004) dealt with the measuring of administrative costs of this tax. Andrlík (2010) has continued their researches. The introduced conclusions of the authors clearly show that the administrative burden of the public sector on the collection of these taxes is very high. The tax efficiency, as one of the fundamental principles based on the tax theory, is not fulfilled in this context. These arguments are therefore against their favour, which is accompanied by political discussions about their cancellation, for example already in 2003, when the deputies of the ODS proposed the complete abolition of the tax, with effect from January 1, 2004 (Poslanecká sněmovna Parlamentu ČR, 2003). The draft of the law was supported by arguments resulting from the tax theory, namely by the existence of multiple taxation or by too low efficiency due to high administrative costs. On the other hand, it is necessary to note that by the implementation of the mentioned revision, the municipal budgets (as 100\% of the beneficiaries of the resources) would lose a considerable source of revenues, which should have been compensated by increasing the percentage share on the revenue of VAT or the income tax. However the given draft of law was rejected.

It is necessary to realize that on the contrary, there are significant voices supporting the existence of TIP. This is especially the fact that they are minimally sensitive to the economic development, they are creating a relatively stable source of revenue for public budgets, or the fact that this income belongs to the municipal budgets in full amount and so it creates their significant source. This paper will focus on the identification of the importance of TIP in the budgets of the municipal units, based on data from 2012 on the territory of the Czech Republic. The aim of this paper is to analyze and evaluate the recurrent tax on immovable property in the Czech Republic, referred as the tax on immovable property. Based on the achieved results there will be subsequently discussed a significance of the tax on immovable property as a part of the incomes of local budgets.

For the implementation of the defined aim it is necessary to study a number of expert resources, particularly the theoretical publications on the topic, which justify or not justify the existence and application of this tax in particular in the context of fiscal decentralization. However, the most important data are the numerical characteristics of the tax available from the official statistics, especially from the Financial Administration of the Czech Republic or from the portal Municipal Budget. A detailed list of used expert sources is listed in the bibliography of this paper. To fulfil objectives of this paper, the basic statistical indicators (average, minimum, maximum values) or correlation analysis will be used.. Processing of this paper is based primarily on the method of analysis as an approach based on the decomposition of a whole into elementary parts. The aim of the analysis is to identify the essential and necessary characteristics of the elementary parts of a whole, the knowledge of their nature and regularity. It is a process that decomposes the researched phenomenon or process into smaller parts in order to know its essence. In the paper there is also used the description, by which we describe the characteristics of a phenomenon or a process. Subsequently conclusions and recommendations are formulated with the application of the method of deduction and synthesis. 


\section{Legislation background and practical application of the tax on immovable property in the Czech Republic}

Analyzed TIP is a tax that is different from other taxes applicable on the territory of the Czech Republic, and that is because of the actual budget allocation of the tax. In the Czech Republic the given issue is regulated by Act no. 243/2000 Coll., on budgetary allocation of taxes, which defines the budget to which the collection of taxes flows. The revenue from the tax on immovable property (according to $\S 4$, paragraph 1 of the given Act) is an income for the municipality on whose territory the property is located. A similar system of tax allocation can be found in other Member States of the European Union. The only exceptions are Italy, Greece, Sweden, Lithuania, Sweden, Belgium and Denmark, which are countries where there is a partial division of the tax collection among more budget levels. The comprehensive overview of the budgetary allocation of taxes in the various states of the European Union is given in Table. 1.

Table 1: Budgetary allocation of the tax on immovable property in the individual EU States

\begin{tabular}{|c|c|c|c|}
\hline Country & Budget & Country & Budget \\
\hline Belgium & $\mathrm{R}, \mathrm{L}$ & Hungary & $\mathrm{L}$ \\
\hline Bulgaria & $\mathrm{L}$ & Germany & $\mathrm{L}$ \\
\hline Czech Republic & $\mathrm{L}$ & Poland & $\mathrm{L}$ \\
\hline Denmark & $\mathrm{R}, \mathrm{L}$ & Portugal & $\mathrm{L}$ \\
\hline Estonia & $\mathrm{L}$ & Austria & $\mathrm{L}$ \\
\hline Finland & $\mathrm{L}$ & Romania & $\mathrm{L}$ \\
\hline France & $\mathrm{L}$ & Greece & $\mathrm{C}, \mathrm{L}$ \\
\hline Ireland & $\mathrm{L}$ & Slovak Republic & $\mathrm{L}$ \\
\hline Italy & $\mathrm{C}, \mathrm{L}$ & Slovenia & $\mathrm{L}$ \\
\hline Cyprus & $\mathrm{C}$ & Spain & $\mathrm{L}$ \\
\hline Lithuania & $\mathrm{C}, \mathrm{L}$ & Sweden & $\mathrm{C}, \mathrm{L}$ \\
\hline Latvia & $\mathrm{L}$ & United Kingdom & $\mathrm{L}$ \\
\hline
\end{tabular}

Source: own work according to sources of European Commission (2013)

Note: $L=$ local budget, $R=$ regional budget, $C=$ central budget

These facts are closely related to fiscal federalism, which deals with the organization of budget systems or appropriate resource allocation to individual budgetary systems. From this perspective it is possible to talk about so called fiscal decentralization where powers from the centre are transferred to the lower territorial units, which are entitled to influence the amount of tax liability, but above all they are recipients of their collection. The method of the use of the collected tax revenues, which it is primarily the responsibility in the provision of public goods and services, is the subject of their subsequent decisions. An unquestionable advantage of the municipal units is their better knowledge of the conditions and needs in the given area, which leads to a greater efficiency when disposing with public funds and thereby the elimination of the loss from the centralization.

From this point of view the TIP is exactly the tax, which plays a significant role in terms of the fiscal decentralization. Professional literature also states that the municipality as the exclusive beneficiaries of the tax collection should have the possibility to influence the final amount of the tax liability of its taxpayers. A possible way how to achieve this is the application of correction mechanisms, such as the application of multiplying coefficients. Czech legislation is familiar with the term of local coefficient, which is regulated in $\S 12$ of 
Act no. 338/1992 Coll., the tax on immovable property, according to which the municipalities can establish by the generally applicable regulation the local coefficient of 2, 3, 4 or 5, which is then valid for all properties on the territory of the municipality. The tax liability of each taxpayer for each land, buildings or units, with the exception of land referred to in $\S 5$, par. 1 (i.e. arable land, vineyards, gardens, orchards and grassland) is then multiplied by the determined coefficient. This correction mechanism is relatively new in the Czech Republic, as its application was introduced only with effect from January 1, 2009, based on the Act no. 261/2007 Coll., on stabilization of public budgets. Requirements of the representatives of municipal units, who often called on to strengthen their interest or competence when influencing tax that flows exclusively into their budgets, were fulfilled by its implementation. The goal of the next section of this paper is to evaluate and assess whether the municipal units use this option, or to look for reasons for its non-application, and all of that in the time period 2009-2014.

Provided data by the Financial Administration of the Czech Republic indicates that the possibility to apply the local coefficient and so the n-fold increase in tax income of the municipality is considered to be underused correction mechanism. Figure 1 shows the development of the number of municipalities that decided to implement it. In 2009, in the year in which it was first possible to apply the local coefficient, only $6.22 \%$ of the municipalities decided for its implementation. The following year was not only the year of municipal elections, which could be one of the many reasons why there has been a reduction in the number of municipal units applying the local coefficient, but also a year when there have been significant legislative changes, specifically to amendment no. 362/2009 Coll., which amends Act no. 338/1992 Coll. in the field of the amount of basic tax rates, which leads to their double. All these may be reasons why the local coefficient was applied only by $4.54 \%$ of the municipalities in this year. The development of the application of the local coefficient had the same trend in 2011. Therefore it can be assumed that there could be a commitment to abolish or reduce the level of local coefficient in the electoral programmes of the newly elected councils. Since 2012 there has been an annual increase in the number of municipalities that apply the local coefficient. The highest value was identified in 2014 , it was $8.30 \%$, which is relatively very low value, because in absolute terms it is only about 519 municipalities out of a total of 6253 municipalities in the Czech Republic.

Figure 1: Development of application of the local coefficient in 2009-2014

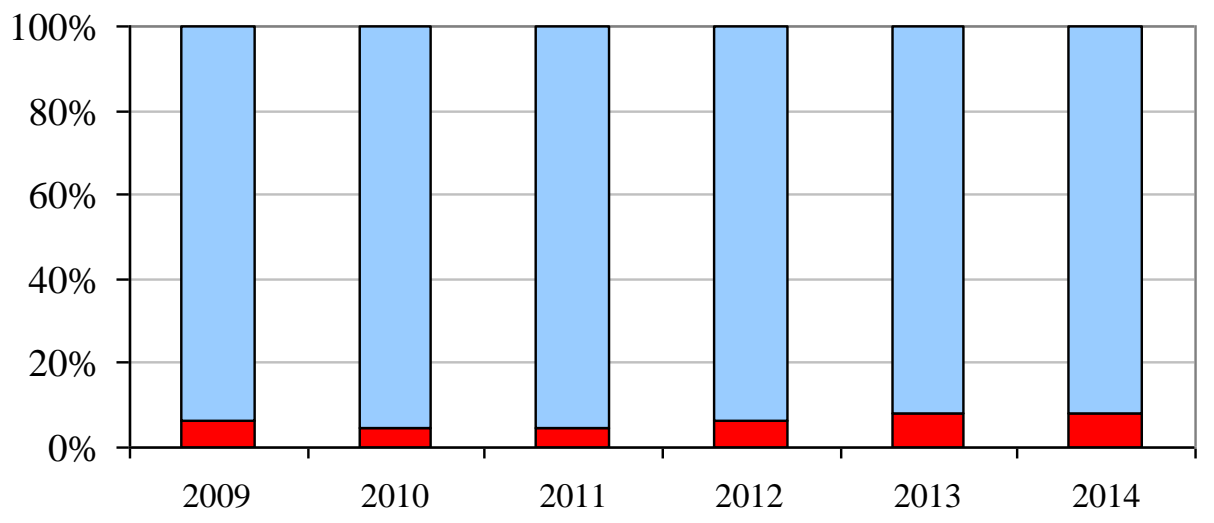

$\square$ Municipality using the local coefficient $\square$ Total number of municipalities in the CR

Source: own work according to source from internal data from Financial Administration of the Czech Republic (2014), Czech Statistical Office (2013b) 
The above introduced data suggests a very low percentage of the application of the local coefficient which may be caused by many factors. Kubátová (2010) introduces one of them and notes that despite the fact that it is a tax which collection flows into municipal budgets and that the obtained funds are used to provide public goods and services, the TIP is very unpopular and causing the aversion. The above mentioned results are not surprising considering the fact that the application of the local coefficient is a responsibility of the representatives of municipal units, who are elected by the people, i.e. by taxpayers. It can be said that concerns about the good election outcome trumps other aspects. Semihradská (2011) expresses the same opinion (2011) and mentions so called political competition. Furthermore she states that the application of local coefficient can influence the voters' decision. Therefore the implementation of this correction mechanism can influence significantly the chances for re-election of political representatives of municipal units. In this context it will be very interesting to observe the development after the local elections, when the authors expect a similar trend.

Upon closer analysis of the application of the local coefficient in the Czech Republic and in given timeline, it was found out that the most commonly used coefficient becomes a coefficient of 2, which is applied on average by $85.09 \%$ of the municipalities in the observed period, the imaginary second place is held by a coefficient of 3 with an average of $10.21 \%$, the third place then occupies coefficient of 5 used by $3.64 \%$ of the municipalities, the least used over the period is the coefficient of 4 , whose average value is only $1.06 \%$. These facts with the detailed number of municipalities applying the local coefficient in the individual variants are shown in the Figure 2.

Figure 2: The development of the application of the local coefficients in the Czech Republic on timeline 2009-2014

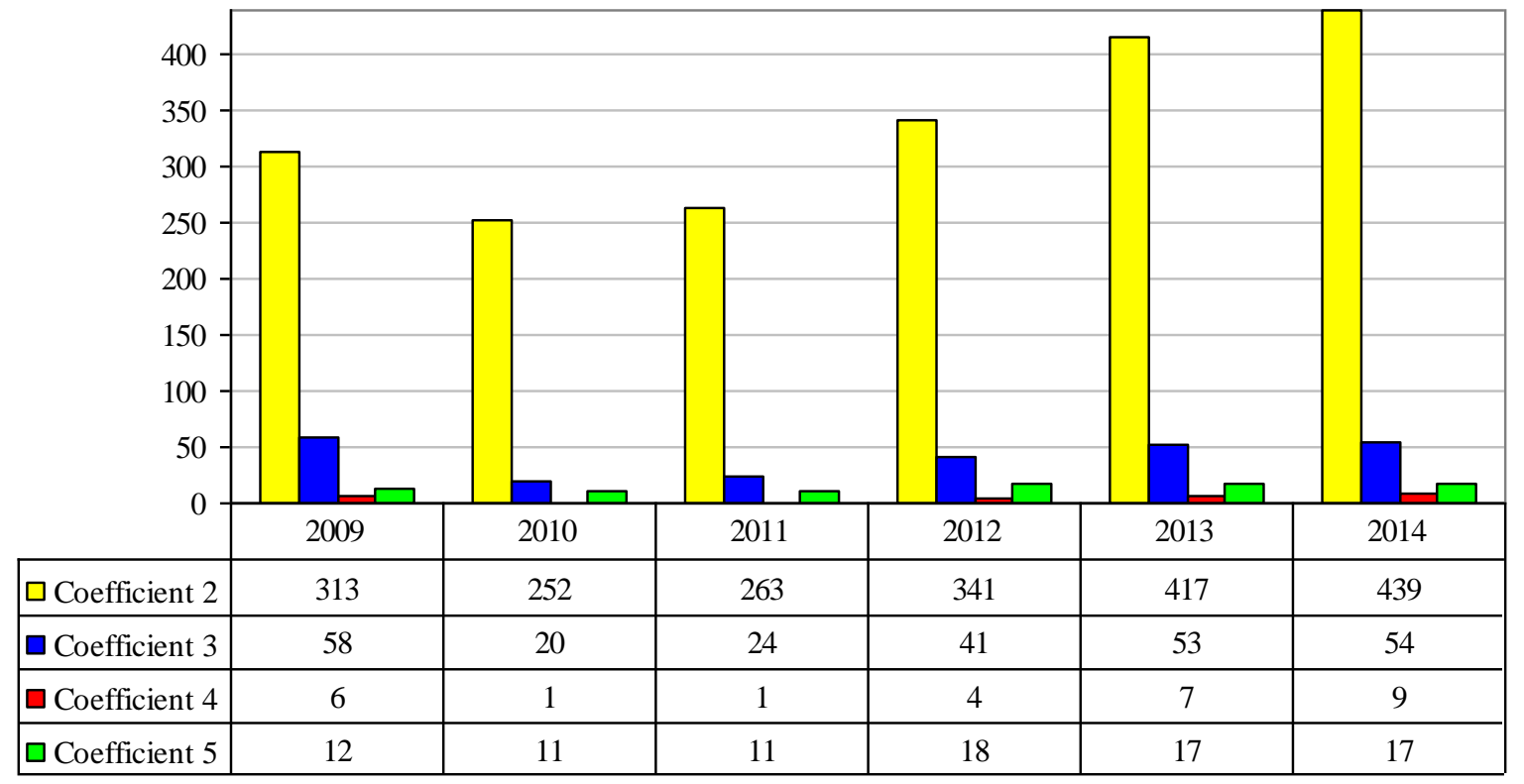

Source: own work according to source from internal data from Financial Administration of the Czech Republic (2014)

From the above given data it can be stated that the local coefficient of 2 is the most widely used coefficient in all monitored years. This fact may be caused by the considerable caution of the representatives of municipal units who choose the so called golden mean, a local coefficient of 2 , in the fear of electoral failure. 
The determination of a final level of the local coefficient is therefore an area, which can be affected by many factors. For example Semihradská (2011) realized her research on the data of time period from 2009 to 2011 . She focused on so called tax mimicking. Using the visual method, she analyzed whether the municipal units in neighborhood are applying the local coefficient at same level. In the conclusion of her article she did not confirm tax mimicking in application of local coefficient. In our analysis we focused on another aspect of local coefficient determination. In the following part of the paper we will answer the researched questions, namely whether the number of the population of the municipality correlates with the final level of the local coefficient. It is considered the assumption that with a growing population, the level of the local coefficient should increase. The evaluation of the correlation of the level of the local coefficient and the number of the population of the given municipality will be carried out on a sample of 494 municipalities. These municipalities decided for the application of the local coefficient in 2013. The final value of the correlation coefficient reaches $|0.086|$, which indicates a very weak correlation between the two variables. Based on this result it may be suggested that the number of population does not have any influence on the amount of local coefficient, i.e. the amount of the local coefficient is not affected by the number of inhabitants. However, it does not exclude the existence of other factors that could affect the amount of the local coefficient.

Figure 3: Correlation of the number of inhabitants and a level of the local coefficient in 2013

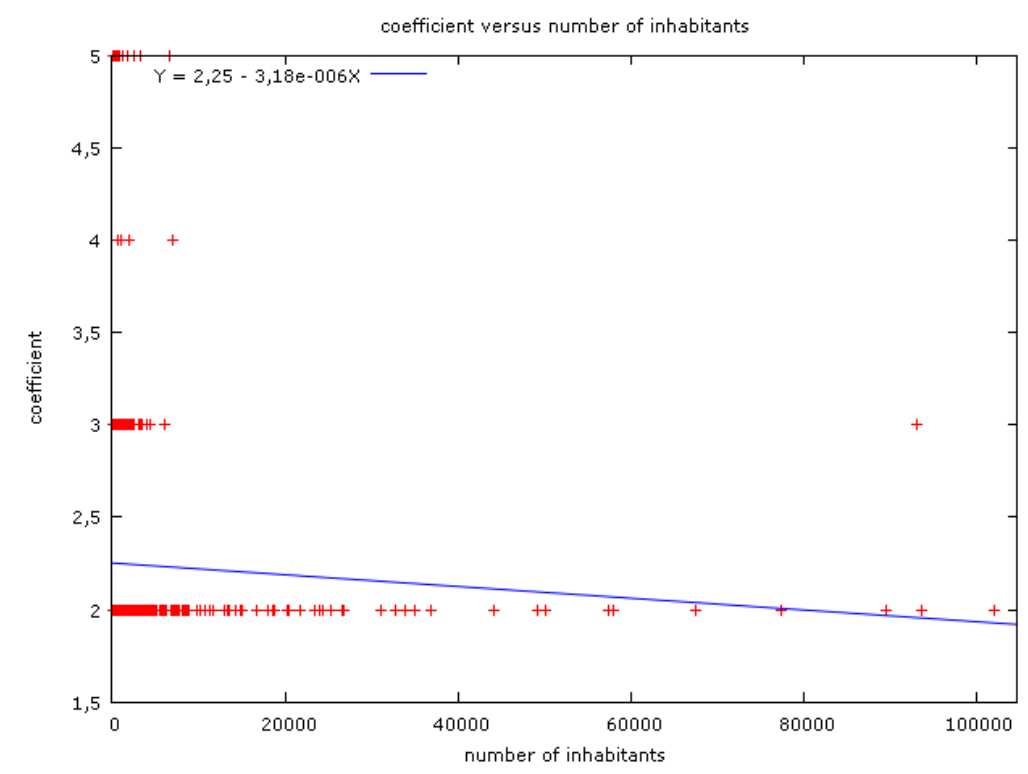

Source: own work according to source of Czech Statistical Office (2013a, 2013b)

Figure 3 shows the obvious fact that the lowest coefficient of 2 is implemented in very different ways from the perspective of the number of population. The coefficient can be found both in municipalities with small populations and even in the municipalities with a large number of populations. Based on the input data, it was found out that the coefficient of 2 is applied in larger municipal units, e.g. in city of Liberec, Pardubice, Most, Znojmo, Vsetín or Mladá Boleslav. The interesting fact is that the highest coefficient (5) is applied by municipalities with very small populations and at such, whose average population is 1260 people. However in determining the studied question there was considered another fact and it was an assumption that with higher number of inhabitants, the local coefficient will be determined at higher values. This view can be supported by the idea that municipalities with higher numbers of inhabitants are forced to incur higher expenditure on the provision of goods and services related mainly to local infrastructure, lighting, public protection, etc. 
Positive correlation between the level of local coefficient and the number of inhabitants of the municipality can be rejected based on the achieved results. Therefore it can be said that the factor of the number of inhabitants is not important in determining the amount of local coefficient, but other facts are. The examples can include location, industrial or tourist attractiveness of municipalities. If we look closer at the municipalities which apply the highest coefficient, we can name the following municipal units - Boží Dar, Dukovany, Temelín, Pikovice, Hulice, Rouchovany, Čeladná, Stonava or Trnávka. From the list of municipalities it can be assumed that the representatives of many municipal units determine coefficient in amount of 5 based on the fact that this is an important industrial and tourist area. The local coefficient in the highest possible level however can cause a number of social problems, as it fivefold increases the resulting tax liability of the taxpayers. From this reason, it is possible to find various compensatory tools that are used to moderate the above mentioned negative aspects. The examples of compensatory instruments can be found for example in the municipality of Čeladná, where there is a contribution to the maintenance of buildings, or in Stonava where there are provided housing allowances.

\section{The significance of the tax on immovable property in budgets of Czech municipalities}

The main aim of this paper is to identify the significance of TIP in terms of municipal units, which are the sole beneficiaries of the collection of this tax. The following part of the paper is focused on the quantification of the percentage share of the TIP on the absolute income of the municipal units. The discovered values will form an important source of information that will be used at the end of this paper. The analysis will be carried out on the data from 2012, which has been obtained from the portal Municipal Budget. This portal provides information on the total income and expenditure of the municipal units in various classifications.

The following Table 2 shows basic statistical characteristics regarding the significance of TIP in the budgets of the municipal units. On average in 2012 the TIP created $13.53 \%$ share on the total tax income, respectively $8.91 \%$ share on the total income of the municipal units.

Table 2: The significance of the TIP in the budget of the municipal units in 2012

\begin{tabular}{|l|c|c|c|}
\hline $\begin{array}{l}\text { The participation of TIP on the total } \\
\text { municipality tax income }\end{array}$ & Average & Maximum & Minimum \\
\hline $\begin{array}{l}\text { The participation of TIP on the total } \\
\text { municipality income }\end{array}$ & $8.91 \%$ & $83.95 \%$ & $0.04 \%$ \\
\hline
\end{tabular}

Source: own work according to sources from Municipal Budget (2013)

The detail results show that the most significant share of the TIP on the total income has been identified in the municipality Vysoká (in the district of Havličkův Brod), where TIP formed $72.67 \%$ of the share. Other municipalities whose share of TIP on the total income of the municipalities exceeded the value of $50 \%$ are Dukovany (dist. Třebíč), Nošovice (dist. Frýdek Místek) Trnávka (dist. Pardubice), Volevčice (dist. Most), Vřesova (dist. Sokolov ) and Žabeň (dist. Frýdek Místek). The analysis of the application of local coefficient indicates that these municipalities applied the coefficient in the highest possible level (i.e. equal to 5) in 2012. The only exception is the municipality Nošovice, whose coefficient was 3 for this year, then Volevčice or Vřesova, where the local coefficient was not applied. Conversely, very negligible importance of TIP (situation when the share from the property tax on the total income was less than $1 \%$ ) was identified in case of 31 municipal units. The lowest value $(0.03 \%)$ was then observed in the municipality Lazsko (dist. Přibram). 
From previous analysis it could seem that TIP has only little meaning in the budgets of the municipal units (especially from the average values). In connection with this fact, there was performed more detailed analysis, the comparison of income and expenditure of the individual municipal units. Firstly, there were compared the income and expenditures of the municipalities in the actual amount, i.e. that were achieved in 2012. Subsequently, there was made a modification of the total income of the municipalities respecting the assumption that TIP does not exist and thus does not constitute the income component into the municipal budgets. The modification consisted in the removing the collection obtained through TIP from the total income of the municipality. These values were furthermore compared with expenditures (ceteris paribus) of the individual municipalities. The dependence of municipalities on TIP was evaluated through final state of the individual budget, which could have surplus or deficit form.

The initial results present the situation where TIP is in a full amount the part of the income of the municipalities. It was found out that 2324 of the municipalities have a deficit budget. In other words, in 2012 there were $37.24 \%$ of the indebted municipalities from the total number of municipalities in the Czech Republic. Subsequently the values of the income of the municipal units were modified. The collection of TIP was removed from the budgets of the affected units assuming the condition of ceteris paribus. After the execution of the given modification, it was found out that there would be an increase of 1205 municipal units that would have a deficit budget. In the absence of TIP, which would cause the loss of resources for municipal budgets, there would be 3529 indebted municipalities in the Czech Republic, which would represent $56.55 \%$ of all municipalities in the Czech Republic. The above introduced facts are shown in Fig. 4. It shows the aggregate incomes of the municipalities in both above discussed variants - incomes including the collection of TIP (Total income including TIP), then also incomes without this component (Total income without TIP) in comparison with the total expenditure (Total expenditure) for all municipalities located in the Czech Republic. The figure shows that the aggregate incomes without TIP does not reach the total expenditure and creates about $98 \%$ of their share.

Figure 4: The comparison of the total incomes and expenditures of the municipal units (in Mil. CZK) in 2012

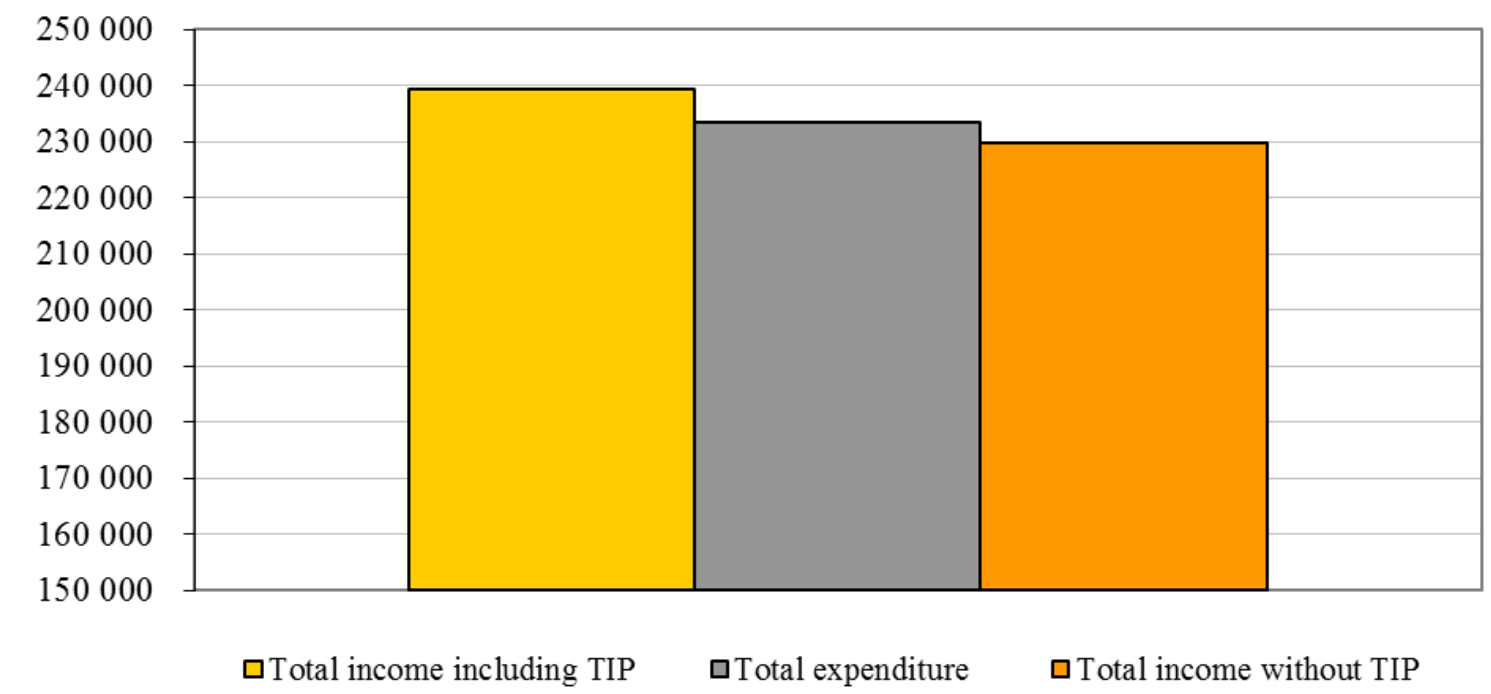

Source: own work according to source from Municipal Budget (2013) 
The above given values do not have enough explicitness, as they were found out from the total incomes and expenditures of all municipalities located in the Czech Republic. From this reason it is therefore necessary to analyze the significance of TIP for the individual municipalities separately. Based on detailed data obtained from the portal Municipal Budget (2013) for the individual municipal units, and after the performance of the partial analysis, it was found out that the level of income without TIP is insufficiently high for 3529 municipal units, because the amount of the income does not reach the values of their expenditure. The given value corresponds with the number of towns and municipalities, whose budget would be deficit in the absence of TIP, mostly there are small municipal units with the average population of 1422 of the inhabitants. In contrast the municipal units that would be able to cover their expenses also without the tax resources form of TIP, can be characterized by the average population of 2015 inhabitants. The following Figure 5 shows the situation of the municipalities in the Czech Republic in case of the absence of TIP as a source of local budgets. The income would be high enough for $43 \%$ of the municipal units and the budget of the municipality would remain in the surplus. The budget of the remaining $57 \%$ of the municipalities would become deficit.

Figure 5: Incomes of the municipal units without the collection of TIP in 2012

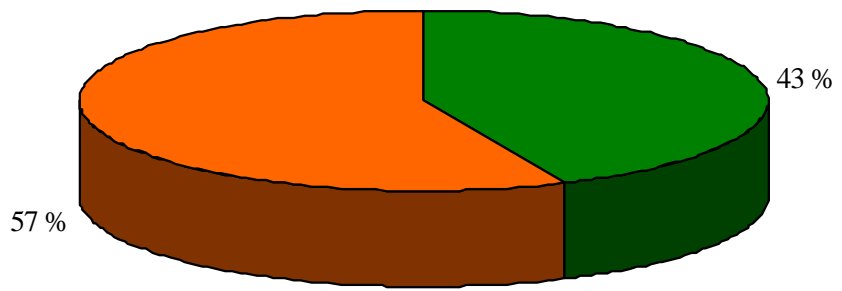

$\square$ municipality income high enough $\square$ municipality income insufficient

Source: own work according to source from Municipal Budget (2013)

Figure 6 shows the situation in case the collection of TIP is still part of the budgets of the municipal units. In this situation, the values are reversed and the income of $63 \%$ of municipalities is sufficiently high, the deficit of the local budget would be identified only in $37 \%$ of the units.

Figure 6: Incomes of the municipal units with the collection of TIP in 2012

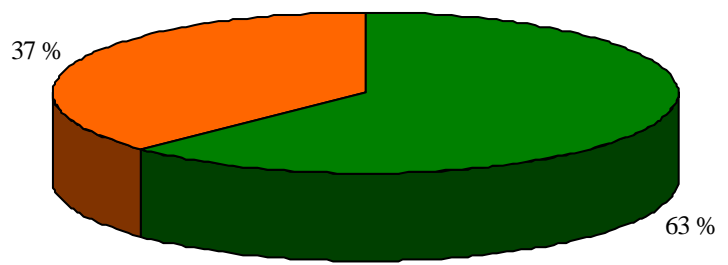

$\square$ municipality income high enough $\square$ municipality income insufficient 
Based on the above mentioned numerical characteristics, the TIP can be considered as a tax which is not so important from the point of the aggregate level, because its average value on the total revenue of the municipalities creates only $8.91 \%$ share. However a more detailed analysis points to the importance of TIP especially for small municipal units (with average population of 1422 inhabitants) which budgets would be deficit in case of absence the analyzed tax. Therefore the TIP can be described as a tax which has its place in the Czech tax system, which was also confirmed by the above performed experiment involving the elimination of TIP as a source to municipal budgets.

\section{Conclusion}

The paper dealt with the issue of the significance of tax on immovable property in the budgets of the municipal units on the territory of the Czech Republic. In the theoretical introduction there was addressed the importance of this tax as part of the tax systems of each modern market economy and defined its meaning in the context of fiscal decentralization. From this perspective, the tax on immovable property is exactly the tax that plays significant role from the point of view of fiscal decentralization. The expert literature also states that the municipality as the sole beneficiaries of the tax collection should be able to influence the final amount of the tax liability of its taxpayers. Since 2009 in the Czech Republic there has been an opportunity to affect the amount of tax revenue of this tax, and in $\S 12$ of Act no. 338/1992 Coll., as amended, which solves the problem of so-called local coefficient. In the context of this paper there was dedicated an important part of the analysis of the significance of this tool and its implementation by individual municipal units. Based on the obtained results it can be noted that the most commonly used coefficient is the coefficient in amount of 2, which is used by $85.09 \%$ municipalities on average in the monitored period, the imaginary second place keeps coefficient of 3 with an average of $10.21 \%$, third place then occupies coefficient of 5 used by $3.64 \%$ of the municipalities, the least used coefficient over the period becomes a coefficient of 4 whose average value is only $1.06 \%$. This fact may be caused by the considerable caution of the representatives of municipal units who choose so called gold mean, a local coefficient in amount of 2 (from the fear of an election failure). The determination of the local coefficient is a problem that can be affected by many factors. For example, in the context of this paper it was tested the correlation of the local coefficient and the number of inhabitants in the selected municipalities. Within our analysis we did not confirm the positive correlation between these variables.

Based on the analysis of significance of tax on immovable property in the budget of the municipality there was performed a measurement, the calculation of the share of the tax on immovable property on the total tax revenues of municipalities and the share of tax on immovable property on the total income of these units. On the basis of achieved results, it was found out that in 2012, according to available data from the portal Municipal Budget (2013), the immovable property tax created $13.53 \%$ of the total tax revenues, respectively $8.91 \%$ on the total revenues of the municipal units. From the performed analysis (especially from the average values), it would seem that TIP has only little meaning in the budgets of the municipal units. In connection with this fact, the detailed analysis was performed. The results show that if the collection of TIP will continue to be a part of the budgets of the municipal units so the income of $63 \%$ of municipalities is high enough and $37 \%$ of the municipalities would have the deficit form of the local budget. Assuming that the immovable property tax would not be included in the income of municipalities, the results are worse. All in all, $43 \%$ of units would have income high enough and the budget of the municipality would remain in surplus. Budget of the remaining 57\% of the municipalities would become deficit. From this perspective, the role of the tax on immovable property in the budgets of the municipalities can 
be considered as very important. Norregaard (2013) also emphasizes the importance of the recurrent tax on immovable property in municipal budgets. If it is strengthened the position of property taxes (i.e. by implementation of local coefficients), the municipalities will be less dependent on transfers. His final statement supports the idea of increased application of property taxes in all individual Member States of the European Union. On the basis of that, we consider as important to recommend the representatives of the municipal units on territory of the Czech Republic to use at least a basic level of the local coefficient more frequently and thus gain sufficient funding to implement their local projects that are intended for citizens of municipal units. After the election to local councils and in terms of conditions of 2014, it is just the perfect time for the introduction of these "negative" and often unpopular measures to increase budget revenues, which ultimately may improve the quality of life of citizens in these municipalities.

\section{References}

[1] ANDRLÍK, B., 2010. Administrativní náklady majetkových daní v České republice. Acta Univ. Agric. Silvic. Mendelianae Brun, LVIII(6), 13-20. ISSN 1211-8516.

[2] ANDRLÍK, B. and L. FORMANOVÁ, 2014. Importance of the recurrent tax on immovable property in the tax systems of EU countries. Acta Universitatis Agriculturae et Silviculturae Mendelianae Brunensis, 62(6), 1213-1220. ISSN 1211-8516.

[3] Český statistický úřad, 2013a. Informace o sčitání lidu [online]. [cit.2013-07-12]. Available at: http://www.scitani.cz/sldb2011/redakce.nsf/i/o_scitani

[4] Český statistický úřad, 2013b. Počet obcí podle krajů (stav k 1.1.) [online]. [cit.2013-1010]. Available at: http://www.czso.cz/cz/cr_1989_ts/0201.xls

[5] European Commission, 2013. Taxation and Customs union - Taxes in Europe database [online]. [cit.2013-10-12]. Available at: http://ec.europa.eu/taxation_customs/tedb/taxSea rch.html

[6] Finanční správa, 2014. Místní koeficienty obcí v letech 2009 - 2014. [cit. 2014-07-16]. Emailová korespondence - číslo jednací 37327/14/7000-31200-050378.

[7] JACKSON, P. M and C. V. BROWN, 2003. Ekonomie veřejného sektoru. 1. vyd. Praha: EUROLEX BOHEMIA. ISBN 80-86432-09-2.

[8] KUBÁTOVÁ, K., 2010. Daňová teorie a politika. 5. vyd. Praha: ASPI. ISBN 978-807357-574-8.

[9] MUNICIPAL BUDGET, 2013. Výběry obci ČR: Obce v ČR v 2012 [online]. [cit.201312-13]. Available at: http://www.rozpocetobce.cz/filtr-obci?filtr_obci\% 5Bbudget_item \%5D=\&filtr_obci\%5Bbudget_item_income $\% 5 \mathrm{D}=\&$ filtr_obci\%5Bbudget _item_expense $\% 5 \mathrm{D}=\&$ filtr_obci\%5Bbudget_item_purpose $\% 5 \mathrm{D}=\&$ filtr_obci\%5Bper_in habitant $\% 5 \mathrm{D}=0 \&$ filtr_obci\% $\% \mathrm{Bkraj} \% 5 \mathrm{D}=\&$ filtr_obci\% $\%$ Bpopulation_range $\% 5 \mathrm{D}=\&$ filtr_ obci\%5Byear\%5D=2012\&filtr_obci\%5Bsort $\% 5 \mathrm{D}=$ desc

[10] MUSGRAVE, R. A. and P. G. MUSGRAVE, 1994. Veřejné finance v teorii a praxi. 1. vyd. Praha: Management Press. ISBN 80-85603-76-4.

[11] NORREGAARD, J., 2013. Taxing Immovable Property - Revenue Potential and Implementation Chalenges. International Monetary Fund: Working Paper, 13/129.

[12] Poslanecká sněmovna Parlamentu České republiky, 2003. Sněmovní tisk 218/0 Návrh zákona o dani $z$ nemovitostí [online]. [cit.2014-03-09]. Dostupné z: http://www.psp.cz/sqw/text/orig2.sqw?idd=6362 
[13] PRABHAKAR, R., 2008. Wealth Taxes: Stories, Metaphors and Public Attitudes. The Political Quarterly, 79(2), 172-178. ISSN 0032-3179.

[14] Právní předpis 362/2009, Sb. zákon, kterým se mění některé zákony v souvislosti s návrhem zákona o státním rozpočtu České republiky na rok 2010

[15] PUDIL, P., V. VYBÍHAL, L. VÍTEK a J. PAVEL, 2004. Zdanění a efektivnost. 1. vyd. Praha: Eurolex Bohemia. ISBN 80-86861-07-4.

[16] SEMIHRADSKÁ, L., 2011. Třetí rok uplatňování místního koeficientu $u$ daně z nemovitostí [online]. [cit. 2015-05-20]. Dostupné z: http://www.dvs.cz/ clanek.asp?id=6482831

[17] Zákon č. 243/2000 Sb., o rozpočtovém určení výnosů některých daní územním samosprávným celkům a některým státním fondům (zákon o rozpočtovém určení daní), ve znění pozdějších předpisů

[18] Zákon č. 261/2007 Sb., o stabilizaci veřejných rozpočtů

[19] Zákon č. 338/1992 Sb., o dani z nemovitých věcí, ve znění pozdějších předpisů

[20] Zákon č. 89/2012 Sb., občanský zákoník, ve znění pozdějších předpisů

[21] Zákonné opatření Senátu č. 344/2013 Sb., o změně daňových zákonů v souvislosti $\mathrm{s}$ rekodifikací soukromého práva 